\title{
Clostridium difficile-associated diarrhea in adults
}

\author{
Susan M. Poutanen, Andrew E. Simor
}

B See related articles pages 19, 27, 33, 45 and 47

\section{Abstract}

CLOSTRIDIUM DIFFICILE IS THE MOST IMPORTANT CAUSE Of nOSOCOMIal diarrhea in adults. Illness may range from mild watery diarrhea to life-threatening colitis. An antecedent disruption of the normal colonic flora followed by exposure to a toxigenic strain of $C$. difficile are necessary first steps in the pathogenesis of disease. Diagnosis is based primarily on the detection of $C$. difficile toxin A or toxin B. First-line treatment is with oral metronidazole therapy. Treatment with oral vancomycin therapy should be reserved for patients who have contraindications or intolerance to metronidazole or who fail to respond to first-line therapy.

CMAJ 2004;171(1):51-8

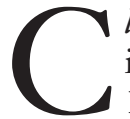

lostridium difficile was first described in $1935,{ }^{1}$ but its association with disease was not identified until $1978 .^{2,3}$ It is now recognized to be an important nosocomial pathogen that may be associated with considerable morbidity and attributable mortality. When exposed to $C$. difficile, some patients become asymptomatic carriers of the organism, whereas others contract $C$. difficile-associated diarrhea, which may range from mild watery diarrhea to life-threatening pseudomembranous colitis. In this review, we summarize the current state of knowledge regarding the epidemiology, pathogenesis, clinical features, diagnostic tests, treatment options and preventive measures for $C$. difficile diarrhea in adults.

\section{Epidemiology}

Based on surveillance conducted in 1997, the incidence of nosocomial $C$. difficile diarrhea in Canadian hospitals is estimated to range from 38 to 95 cases per 100000 patientdays and from 3.4 to 8.4 cases per 1000 admissions. ${ }^{4}$ These rates are comparable to those reported in studies conducted outside of Canada. ${ }^{5}$ C. difficile-associated colitis has been identified as the direct cause of death in $1 \%-2 \%$ of affected patients, and the estimated annual cost per year per facility for readmissions due to nosocomial $C$. difficile diarrhea is $\$ 128200 . .^{6}$ The incidence of community-acquired $C$. difficile diarrhea appears to be substantially lower than rates observed in hospitals, with an estimate of 7.7-12 cases per 100000 person-years. ${ }^{7,8}$ The estimated prevalence of $C$. difficile colonization varies depending on the patient population studied. Among hospital inpatients the prevalence of culture positivity ranges from $7 \%$ to $11 \%{ }^{9,10}$ In long-term care facilities, the estimated prevalence is slightly lower, ranging from $5 \%$ to $7 \% .{ }^{11,12}$ Among ambulatory adults, the prevalence is even lower, generally less than $2 \%{ }^{13,14}$

The primary reservoirs of $C$. difficile include colonized or infected patients and contaminated environments and surfaces within hospitals and long-term care facilities. ${ }^{10,15-18}$ The hands of hospital personnel caring for patients with $C$. difficile often become colonized with the organism, facilitating transmission among hospital inpatients. ${ }^{10}$ In one study, the risk of colonization was found to increase in direct proportion to the length of hospital stay, ranging from $1 \%$ among patients admitted for less than 1 week to as high as $50 \%$ among patients admitted for more than 4 weeks; this suggests that ongoing exposure to $C$. difficile occurs throughout the hospital stay. ${ }^{19}$

Mature colonic bacterial flora in a healthy adult is generally resistant to $C$. difficile colonization. ${ }^{20,21}$ However, if the normal colonic flora is altered, resistance to colonization is lost. Thus, any factor associated with alteration of the normal enteric flora increases the risk of $C$. difficile colonization after exposure to the organism. The most common risk factor isf exposure to antibiotics, especially those with broad-spectrum activity such as penicillins, cephalosporins and clindamycin. ${ }^{22}$ Exposure to antineoplastic chemotherapy or immunosuppressive agents has less commonly been described as a risk factor. ${ }^{23-25}$ Increasing age and severe underlying illness have been determined to be independent risk factors and may reflect age-related or disease-related changes in fecal flora. ${ }^{26-28}$ Gastrointestinal surgery and use of nasogastric tubes, stool softeners, gastrointestinal stimulants, antiperistaltic drugs, antacids and enemas have also been associated with an increased risk of colonization. ${ }^{26-28}$

Not everyone colonized with the organism experiences C. difficile diarrhea. In fact, studies have shown that colonization with $C$. difficile protects against the development of symptomatic disease. ${ }^{19,29,30}$ Shim and associates reported that diarrhea developed in only $1 \%$ of 192 patients asymptomatically colonized with $C$. difficile on admission to hospital compared with $3.6 \%$ of 618 patients not colonized with the organism on admission $(p=0.02) .^{29}$ The risk of diarrhea is also related to the virulence of the infecting $C$. difficile strain $^{21}$ and to the immune response to the organism's toxins. A prospective study by Kyne and associates showed that patients who were recently colonized with $C$. difficile and who had a high serum antibody response to $C$. difficile 
toxin A were usually protected against diarrhea and remained asymptomatic carriers. ${ }^{30}$ In contrast, patients who had low serum antibody responses to toxin A had a much greater risk of diarrhea. These findings suggest that antibody response to toxin A protects against the development of $C$. difficile diarrhea.

The epidemiology of $C$. difficile infection in neonates and infants is distinct from that in older children and adults. Neonates are more likely to carry toxigenic strains of $C$. difficile asymptomatically in the gastrointestinal tract, although the rate of colonization and the proportion of colonized infants with detectable toxin decrease with age. ${ }^{14,31}$ It has been proposed that immature neonatal colonic flora permits $C$. difficile colonization, ${ }^{21}$ and the relative lack of disease despite the presence of toxin is thought to relate to the immaturity of enterocytes lacking toxin A receptors. ${ }^{32}$ The source of $C$. difficile in neonates is believed to be either the mother's vaginal flora or the health care environment. ${ }^{33,34}$ In older children, day-care reservoirs for acquisition of $C$. difficile have been described. ${ }^{35}$

\section{Pathogenesis}

C. difficile is an anaerobic gram-positive spore-forming bacillus. The ability of $C$. difficile to form spores is thought to be a key feature in enabling it to persist in patients and the physical environment for long periods and thereby facilitating its transmission. C. difficile is transmitted through the fecal-oral route. The pathogenesis of the bacillus is shown in Fig. 1. Based on hamster models, most ingested vegetative cells are killed in the stomach, with only $1 \%$ of the inoculum passing into the small bowel. ${ }^{21,36} \mathrm{C}$. difficile spores, however, are acid resistant and readily pass through the stomach; they may germinate in the small bowel upon exposure to bile acids. A number of virulence factors, including flagellae and hydrolytic enzymes produced by the organism, have been associated with the development of disease. ${ }^{37,38}$ However, the best characterized and most important virulence factors are the $C$. difficile exotoxins, toxins $\mathrm{A}$ and $\mathrm{B} .{ }^{39-41}$

Toxins $\mathrm{A}$ and $\mathrm{B}$ are both cytotoxic for a number of different cell types (B is a significantly more potent cytotoxin than A), both cause increased vascular permeability by opening tight junctions between cells, and both cause hemorrhage. ${ }^{39,40}$ They both also induce the production of tumour necrosis factor-alpha and proinflammatory interleukins, which contribute to the associated inflammatory response and pseudomembrane formation. ${ }^{40}$ Colonic pseudomembranes have a distinct appearance, with inflamed mucosa studded with adherent raised white and yellow plaques. Histologically the pseudomembranes are composed of neutrophils, fibrin, mucin and cellular debris.

Only toxigenic strains are associated with the development of $C$. difficile diarrhea. In adults who are asymptomatic carriers of $C$. difficile, these toxins are found less frequently. ${ }^{14}$ Toxin $\mathrm{A}$ is thought to play a more critical role than toxin $\mathrm{B}$ in the pathogenesis of $C$. difficile diarrhea be- cause only it is associated with extensive tissue damage and fluid accumulation in experimental animal models..$^{39,41}$ Toxin $\mathrm{B}$, on the other hand, has no noticeable direct enterotoxic activity and is thought to play a role only after the gastrointestinal wall has been damaged by toxin $\mathrm{A} \cdot{ }^{40,41}$ However, as toxin A-negative/toxin B-positive virulent $C$. difficile strains have been described, it is clear that toxin $\mathrm{A}$ is not essential for virulence. ${ }^{42,43}$

In summary, at least 3 events must occur in the pathogenesis of $C$. difficile diarrhea: alteration of the normal fecal flora, colonic colonization with toxigenic $C$. difficile and growth of the organism with elaboration of its toxins (Fig. 2).

\section{Clinical presentation}

The incubation period from ingestion of $C$. difficile to onset of symptoms has not been determined. However, time from antibiotic exposure to onset of symptoms has been as short as 1 day to as long as 6 weeks or even longer. ${ }^{44,45}$ Illness associated with $C$. difficile ranges from mild diarrhea to life-threatening colitis. ${ }^{45,46}$ Typical clinical features include watery diarrhea, lower abdominal pain and systemic symptoms such as fever, anorexia, nausea and malaise. Leukocytosis and occult colonic bleeding frequently occur, but grossly bloody stools are uncommon. Diffuse or patchy colitis, with or without pseudomembranes, can be seen on colonic endoscopy. ${ }^{45}$ Fulminant colitis occurs among $1 \%-3 \%$ of patients and is characterized by signs and symptoms of severe toxicity with fever and diffuse abdominal pain and distention. ${ }^{479}$ Although diarrhea may be present, severely ill patients may have little or no diarrhea as a result of toxic dilatation of the colon (toxic megacolon) and paralytic ileus that may result from loss of colonic muscular tone.$^{45,49}$ Complications include colonic perforation and peritonitis. ${ }^{45,48}$ Mortality associated with toxic megacolon is high, ranging from $24 \%$ to $38 \% .{ }^{49-52}$

Recurrent diarrhea is seen in $5 \%-40 \%$ of patients receiving treatment for $C$. difficile diarrhea. ${ }^{53-56}$ Kyne and associates showed that independent risk factors for recurrent $C$. difficile diarrhea include age greater than 65 years, increased severity of underlying disease and exposure to additional antibiotics after treatment. ${ }^{54}$ Controlling for these factors, they also showed that a low serum antibody response to toxin A during an initial episode of $C$. difficile diarrhea is associated with an increased risk of recurrence. Up to almost half of recurrences have been shown to be caused by reinfection rather than by relapse, which suggests that reexposure to $C$. difficile from other patients or from the environment is a major source of recurrent symptoms. ${ }^{55,56} \mathrm{In}$ those with true relapse, however, recurrence of symptoms is most likely caused by the intraluminal persistence of $C$. difficile spores that germinate after antibiotic therapy is discontinued. ${ }^{57}$ Relapse due to antibiotic resistance is not thought to be common, given the high intraluminal concentrations of antibiotics that can be achieved and the relatively rare occurrence of antimicrobial resistance in vitro. ${ }^{58}$ 


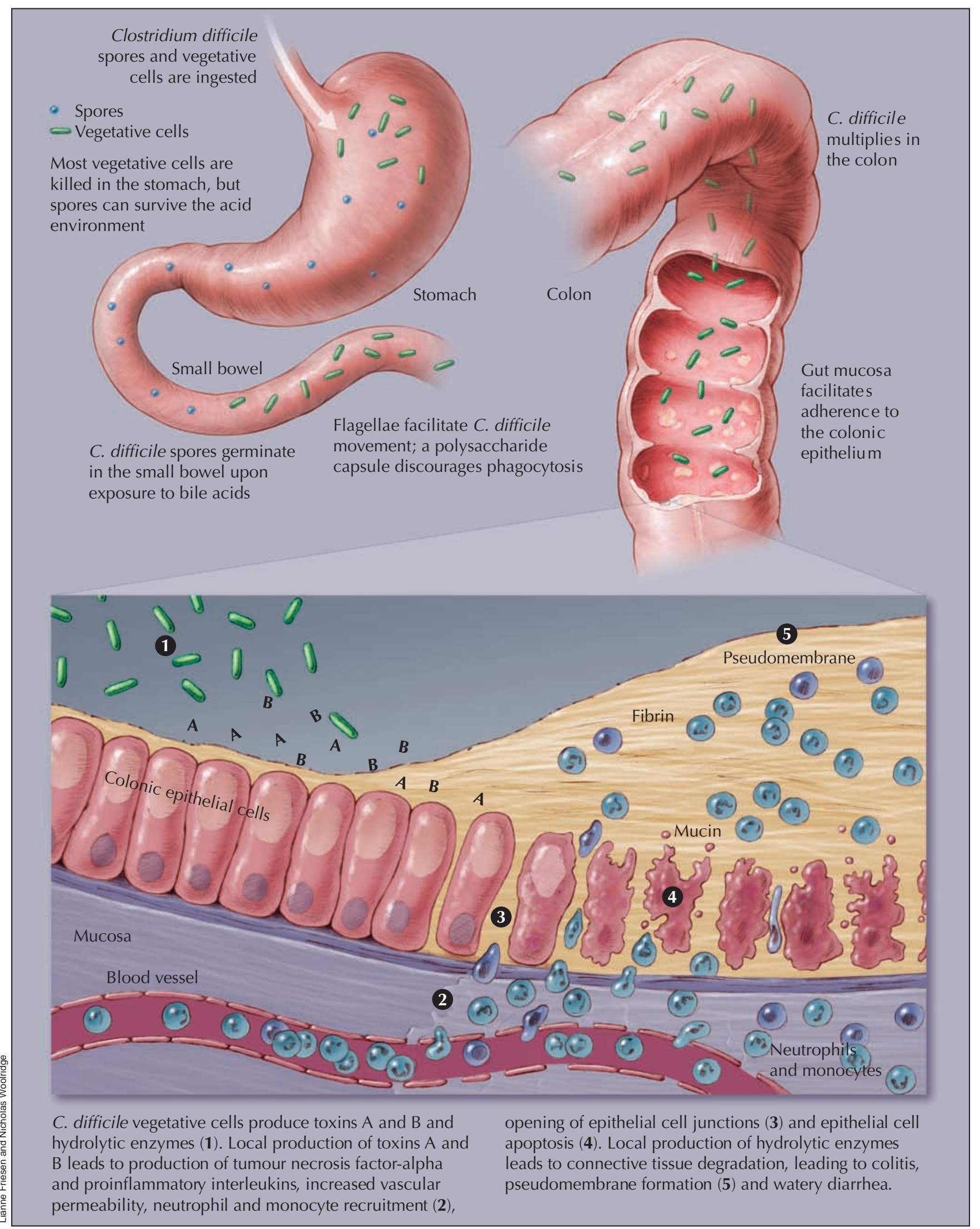

Fig. 1: Pathogenesis of Clostridium difficile-associated diarrhea in adults. 


\section{Diagnosis}

The diagnosis of $C$. difficile diarrhea should be considered in any patient with nosocomial diarrhea, especially if fever is also present. Abdominal imaging studies, including CT scans, may reveal "thumbprinting" of colonic mucosa, which suggests the presence of mucosal edema, but these changes are not specific for pseudomembranous colitis due to $C$. difficile. Direct visualization of colonic mucosa using either sigmoidoscopy or colonoscopy is required to determine the presence of pseudomembranous colitis. However, C. difficile colitis or diarrhea may occur without pseudomembrane formation, and colitis may be missed if only proximal disease is present. In general, sigmoidoscopy and colonoscopy should be avoided in fulminant colitis because of the risk of toxic megacolon and perforation.

A summary of the laboratory methods available for the diagnosis of $C$. difficile diarrhea is shown in Table 1. Diagnosis is generally based on the detection of toxin A or toxin $\mathrm{B}$. The tissue culture cytotoxicity assay detecting the presence of $C$. difficile cytotoxin (toxin B) in stool filtrate is considered to be the "gold standard" for diagnosis because of its high specificity $(99 \%-100 \%) .59,60$ The sensitivity of this test is $80 \%-90 \%{ }^{61,62}$ Performance of the test requires a tissue culture facility, and results are usually not available for at least 48 hours. Nonspecific cytopathic effects may be ob-

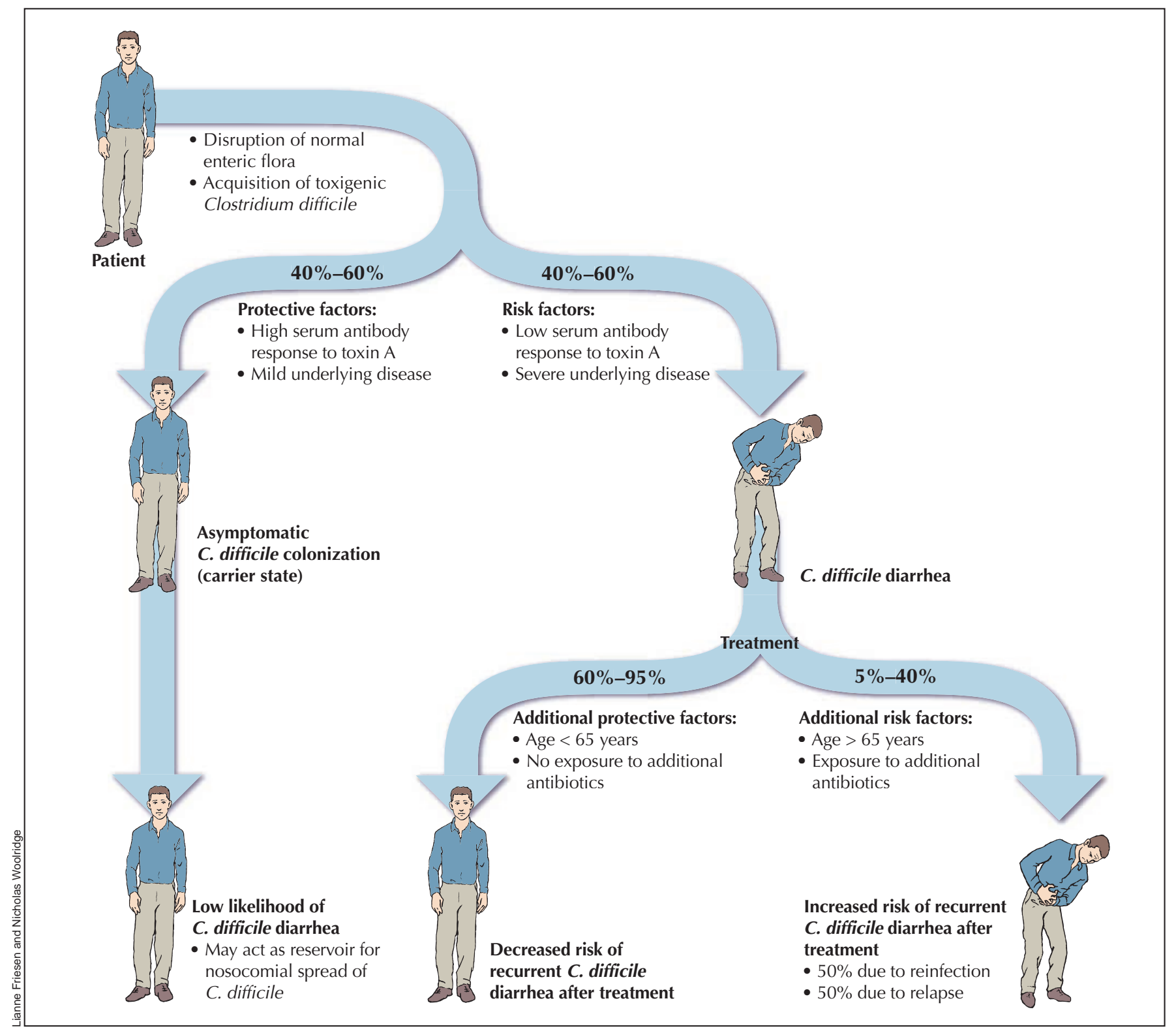

Fig. 2: Factors contributing to the development of Clostridium difficile colonization and diarrhea [adapted, with permission, from Johnson S, Gerding DN. Clostridium difficile-associated diarrhea. Clin Infect Dis 1998;26:1027-36, published by the University of Chicago Press, Infectious Diseases Society of America; 1998]. 
served in approximately $2 \%$ of cases, which makes interpretation of test results impossible. ${ }^{60}$

Rapid enzyme immunoassays have been developed for the detection of toxin A or both toxins A and B from stool filtrates. ${ }^{61-64}$ Test kits able to detect both toxins are more sensitive because they are also able to identify disease caused by toxin A-negative/toxin B-positive strains of $C$. difficile. One of the main advantages of these immunoassays is their rapidity, with results available within hours. However, these tests have reduced sensitivity $(65 \%-85 \%)$ and specificity $(95 \%-100 \%)$ as compared with the cytotoxicity assay. ${ }^{61,62}$

Stool culture for detection of the organism is generally less useful because of the potential for asymptomatic carriage of $C$. difficile strains that are nontoxigenic. ${ }^{14}$ Stool culture associated with detection of toxigenicity is potentially a more useful diagnostic test, with improved sensitivity (> 90\%) and specificity (>98\%). ${ }^{62,64}$ The procedure is labour-intensive and results are not available for at least 72-96 hours. Therefore, few laboratories routinely do stool cultures for $C$. difficile. However, stool culture does have the advantage of enabling strain typing for investigation of an outbreak..$^{65}$

A latex agglutination test that detects the presence of a common clostridial protein, glutamate dehydrogenase, is available. The test is rapid and simple to perform but does not have adequate sensitivity $(58 \%-68 \%)$ or specificity $(90 \%-96 \%)$ for the accurate diagnosis of $C$. difficile diarrhea. ${ }^{64,65}$ Recently, polymerase chain reaction (PCR) methods for the detection of $C$. difficile toxin $\mathrm{A}$ or $\mathrm{B}$, or both, have been developed with excellent sensitivity (92\%-97\%) and specificity (100\%) as compared with the tissue culture cytotoxicity assay. ${ }^{66-68}$ However, standardization of PCR assays for $C$. difficile toxin detection has not been completed and commercial PCR assays are not currently available.

The processing of a single stool specimen for toxin detection at the onset of symptoms is generally sufficient to establish the diagnosis. ${ }^{65,69,70}$ It is recommended that tests for C. difficile or its toxins be done only on diarrheal (unformed) stool specimens unless an ileus is present. ${ }^{65,70}$ There is no value to testing stools of asymptomatic patients, including follow-up for "test-of-cure," unless an outbreak is being investigated.

\section{Treatment}

Treatment guidelines and recent reviews of recommended treatment for $C$. difficile diarrhea have been published and are summarized in Box $1 .^{53,57,65,70,71}$ The most important first step in treatment is cessation of the inciting agent, most commonly antibiotics, if this is deemed to be medically appropriate. For mild disease, this is often sufficient for full recovery. ${ }^{70,72}$ For more severe disease, antimicrobial therapy directed against $C$. difficile is required. Oral metronidazole therapy $(250 \mathrm{mg} 4$ times daily or $500 \mathrm{mg}$ twice daily) given for 10-14 days is recommended as the initial treatment of choice. ${ }^{65,70}$ Vancomycin $(125 \mathrm{mg}$ orally 4 times daily [for 10-14 days]) is the recommended secondline therapy. ${ }^{65,70,73}$ Metronidazole and vancomycin are comparable with regard to efficacy and relapse rates. ${ }^{74,75}$ Given the higher cost of oral vancomycin therapy and concern about selection for vancomycin-resistant enterococci, ${ }^{76}$ metronidazole is preferred as the initial agent of choice. ${ }^{65,70,71}$ Vancomycin should be reserved for patients with contraindications or intolerance to metronidazole or for those who fail to respond to metronidazole. Alternative antibiotic therapies for $C$. difficile diarrhea include oral therapy with teicoplanin (not available in Canada), bacitracin (not available in Canada) or fusidic acid, although these agents have not been studied as extensively as metronidazole and vancomycin. ${ }^{74,77-79}$ In addition to specific antimicrobial therapy, supportive therapy with hydration and correction of electrolyte abnormalities is important in patients with $C$. difficile diarrhea. Antiperistaltic drugs should be avoided because they may precipitate toxic megacolon. ${ }^{65,70}$

Controlled clinical trials are lacking for patients with fulminant colitis who may not tolerate oral therapy. Administration of metronidazole intravenously or administration of vancomycin by nasogastric tube or rectal enema has been described in small case series. ${ }^{57,71,80,81}$ Intravenous administration of vancomycin is not recommended because the drug is not excreted into the colon. ${ }^{57}$ Intravenous immunoglobulin therapy has been used with success in a small number of patients with fulminant disease. ${ }^{82}$ Surgical intervention is indicated for patients who are not responding to

\begin{tabular}{|c|c|c|}
\hline Test & Advantages & Disadvantages \\
\hline C. difficile cytotoxin assay & Excellent specificity $(99 \%-100 \%)$ & $\begin{array}{l}\text { Decreased diagnostic sensitivity }(80 \%-90 \%) \\
\text { Test results not available until after } 48 \mathrm{~h} \\
\text { Requires tissue culture facility } \\
\text { Detects only toxin B }\end{array}$ \\
\hline $\begin{array}{l}\text { Immunoassay for detection } \\
\text { of toxin } A \text { or toxins } A \text { and } B\end{array}$ & $\begin{array}{l}\text { Good specificity }(95 \%-100 \%) \\
\text { Test results available within } 4 \mathrm{~h} \\
\text { Technically simple }\end{array}$ & $\begin{array}{l}\text { Reduced sensitivity }(65 \%-85 \%) \text { as } \\
\text { compared with cytotoxin assay }\end{array}$ \\
\hline $\begin{array}{l}\text { Stool culture to isolate } \\
\text { C. difficile with subsequent } \\
\text { cytotoxin assay of isolate }\end{array}$ & $\begin{array}{l}\text { Excellent sensitivity (>90\%) and } \\
\text { specificity (>98\%) } \\
\text { Enables typing of strain for outbreak } \\
\text { investigation }\end{array}$ & $\begin{array}{l}\text { Results not available for at least } 72-96 \mathrm{~h} \\
\text { Labour-intensive } \\
\text { Requires tissue culture facility }\end{array}$ \\
\hline
\end{tabular}


medical treatment or when colonic perforation or toxic megacolon is suspected. .11,52,83

Unfortunately, recurrent $C$. difficile diarrhea occurs in about $5 \%-20 \%$ of patients after treatment with either metronidazole or vancomycin. ${ }^{53,55,70}$ Metronidazole remains the drug of choice for treatment of an initial recurrence even if this was the original drug used..$^{57,65,70}$ For patients with multiple relapses, tapered and pulsed antibiotic therapy with metronidazole or vancomycin has been used. ${ }^{57,84,85}$ Treatment with rifampin in combination with vancomycin $^{86}$ or with anion-binding resins such as colestipol or cholestyramine has been found to be helpful for some patients. ${ }^{87}$ Adjunctive therapy with probiotic agents such as Saccharomyces boulardii $i^{88-90}$ and Lactobacillus $G G^{91}$ has also been found to be effective in the management of a relatively small number of patients with recurrent $C$. difficile diarrhea. Further evaluation of treatment modalities for recurrent $C$. difficile colitis is required.

\section{Preventive measures}

Comprehensive guidelines and review articles summarizing strategies for the prevention of nosocomial transmission of $C$. difficile and for the prevention of $C$. difficile diarrhea have been published. ${ }^{65,92,93}$ Prevention of nosocomial transmission of $C$. difficile depends on careful attention to handwashing, isolation and barrier precautions, and cleaning of the physical environment throughout the duration of symptomatic disease. Hand hygiene and glove use have been shown to be effective in preventing nosocomial transmission of $C$. difficile. ${ }^{94,95}$ Because clostridial spores may be relatively resistant to alcohol and other antiseptic agents, it has been recommended that hands be washed with soap and water af-

\section{Box 1: Recommended treatment of Clostridium difficile-associated diarrhea in adults ${ }^{53,57,65,70,71}$}

\section{First-line treatment}

Discontinuation of antibiotics if possible

Metronidazole orally (250 mg 4 times daily or $500 \mathrm{mg}$ twice daily) for 10-14 d (give metronidazole intravenously if patient is unable to take medications orally)

\section{Alternative treatment}

Vancomycin orally (125 mg 4 times daily) for 10-14 d

\section{Treatment of recurrent disease}

Repeat treatment with metronidazole or vancomycin Bacitracin (25 $000 \mathrm{U}$ orally 4 times daily) Adjunctive treatment with Saccharomyces boulardii (500 mg orally twice daily) or Lactobacillus GG $\left(20 \times 10^{9}\right.$ colony-forming units/d)

Adjunctive therapy with cholestyramine (4 g 3 times daily) ter glove removal during outbreaks of $C$. difficile-associated infections. ${ }^{96}$ The use of private rooms with implementation of enteric or contact precautions has been successful in limiting transmission of $C$. difficile in hospital and long-term care settings. ${ }^{97-101}$ Because this measure has generally been introduced along with other infection control measures, it is not known how effective it would be if used alone.

The physical hospital environment of patients with $C$. difficile infection is often contaminated and has been implicated as a reservoir for transmission of the organism to other patients. ${ }^{100}$ Therefore, meticulous cleaning of surfaces and equipment and disinfection with agents able to eradicate $C$. difficile and its spores, such as a diluted hypochlorite solution, have been recommended..$^{70,92,100}$

Strategies aimed at preventing the development of $C$. difficile diarrhea include antibiotic restriction, the use of probiotics, and passive and active immunization. Antibiotic restriction has been shown to be associated with decreased rates of nosocomial $C$. difficile diarrhea, and therefore programs encouraging the proper use of antibiotics are an important preventive strategy. ${ }^{101-103}$ The use of probiotic agents throughout the duration of antibiotic use as a means of preventing C. difficile diarrhea in high-risk patients has been evaluated as a possible preventive therapy, with mixed results. ${ }^{104-106} \mathrm{C}$. difficile toxin vaccines have been developed, and their safety and immunogenicity are currently being evaluated. ${ }^{107,108}$

This article has been peer reviewed.

From the Department of Microbiology, Toronto Medical Laboratories and Mount Sinai Hospital (Poutanen), the Department of Laboratory Medicine and Pathobiology, University of Toronto (Poutanen, Simor) and the Departments of Microbiology and Medicine, Sunnybrook and Women's College Health Sciences Centre (Simor), Toronto, Ont.

Competing interests: None declared.

Contributors: Susan Poutanen wrote the first draft of the manuscript. Both authors contributed to the conception and design of the literature review, reviewed the relevant papers, contributed to final revisions of the manuscript and gave final approval of the submitted version to be published.

\section{References}

1. Hall IC, O'Toole E. Intestinal flora in newborn infants with a description of a new pathogenic anaerobe, Bacillus difficilis. Am 7 Dis Child 1935;49:390-402.

2. George RH, Symonds JM, Dimock F, Brown JD, Arubi Y, Shinagawa N, et al. Identification of Clostridium difficile as a cause of pseudomembranous colitis. $B M 71978 ; 1: 695$.

3. Larson HE, Price AB, Honour P, Borriello SP. Clostridium difficile and the aetiology of pseudomembranous colitis. Lancet 1978;1:1063-6.

4. Hyland M, Ofner-Agostini ME, Miller MA, Paton S, Gourdeau M, Ishak M. Nosocomial Clostridium difficile-associated diarrhea in Canada: the results of the Canadian Nosocomial Infection Surveillance Program (CNISP) 1997 NCDAD prevalence surveillance project. Can 7 Infect Dis 2001;12:81-8.

5. Riley TV, O'Neill GL, Bowman RA, Golledge CL. Clostridium difficile-associated diarrhoea: epidemiological data from Western Australia. Epidemiol Infect 1994;113:13-20.

6. Miller MA, Hyland M, Ofner-Agostini M, Gourdeau M, Ishak M. Morbidity, mortality, and healthcare burden of nosocomial Clostridium difficile-associated diarrhea in Canadian hospitals. Infect Control Hosp Epidemiol 2002;23:137-40.

7. Hirschhorn LR, Trnka Y, Onderdonk A, Lee ML, Platt R. Epidemiology of community-acquired Clostridium difficile-associated diarrhea. 7 Infect Dis 1994; 169:127-33

8. Levy DG, Stergachis A, McFarland LV, Van Vorst K, Graham DJ, Johnson ES, et al. Antibiotics and Clostridium difficile diarrhea in the ambulatory care setting. Clin Ther 2000;22:91-102. 
9. Samore MH, DeGirolami PC, Tlucko A, Lichtenberg DA, Melvin ZA, Karchmer AW. Clostridium difficile colonization and diarrhea at a tertiary care hospital. Clin Infect Dis 1994;18:181-7.

10. McFarland LV, Mulligan ME, Kwok RYY, Stamm WE. Nosocomial acquisition of Clostridium difficile infection. N Engl 7 Med 1989;320:204-10.

11. Walker KJ, Gilliland SS, Vance-Bryan K, Moody JA, Larsson AJ, Rotschafer $\mathrm{JC}$, et al. Clostridium difficile colonization in residents of long-term care facilities: prevalence and risk factors. 7 Am Geriatr Soc 1993;41:940-6.

12. Rivera EV, Woods S. Prevalence of asymptomatic Clostridium difficile colonization in a nursing home population: a cross-sectional study. 7 Gender-Specific Med 2003;6:27-30.

13. Aronsson B, Möllby R, Nord CE. Antimicrobial agents and Clostridium difficile in acute enteric disease: epidemiological data from Sweden, 1980-82. 7 Infect Dis 1985;151:476-81.

14. Viscidi R, Willey S, Bartlett JG. Isolation rates and toxigenic potential of Clostridium difficile isolates from various patient populations. Gastroenterol 1981;81:5-9.

15. Cohen SH, Tang YJ, Rahmani D, Silva J Jr. Persistence of an endemic (toxigenic) isolate of Clostridium difficile in the environment of a general medicine ward. Clin Infect Dis 2000;30:952-4.

16. Fawley WN, Wilcox MH. Molecular epidemiology of endemic Clostridium difficile infection. Epidemiol Infect 2001;126:343-50.

17. Titov L, Lebedkova N, Shabanov A, Tang YJ, Cohen SH, Silva J Jr. Isolation and molecular characterization of Clostridium difficile strains from patients and the hospital environment in Belarus. 7 Clin Microbiol 2000;38:1200-2.

18. Clabots CR, Johnson S, Olson MM, Peterson LR, Gerding DN. Acquisition of Clostridium difficile in hospitalized patients: evidence for colonized new admissions as a source of infection. I Infect Dis 1992;166:561-7.

19. Johnson S, Clabots CR, Linn FV, Olson MM, Peterson LR, Gerding DN. Nosocomial Clostridium difficile colonisation and disease. Lancet 1990;336:97-100.

20. Borriello SP. The influence of the normal flora on Clostridium difficile colonisation of the gut. Ann Med 1990;22:61-7.

21. Wilson KH. The microecology of Clostridium difficile. Clin Infect Dis 1993; 16(Suppl 4):S214-8.

22. Bignardi GE. Risk factors for Clostridium difficile infection. 7 Hosp Infect 1998; 40:1-15.

23. Anand A, Glatt AE. Clostridium difficile infection associated with antineoplastic chemotherapy: a review. Clin Infect Dis 1993;17:109-13.

24. Blot E, Escande MC, Besson D, Barbut F, Granpeix C, Asselain B, et al. Outbreak of Clostridium difficile-related diarrhoea in an adult oncology unit: risk factors and microbiological characteristics. 7 Hosp Infect 2003;53:187-92.

25. Sharma AK, Holder FE. Clostridium difficile diarrhea after use of tacrolimus following renal transplantation. Clin Infect Dis 1998;27:1540-1.

26. McFarland LV, Surawicz CM, Stamm WE. Risk factors for Clostridium difficile carriage and C. difficile-associated diarrhea in a cohort of hospitalized patients. 7 Infect Dis 1990;162:678-4.

27. Simor AE, Yake SL, Tsimidis K. Infection due to Clostridium difficile among elderly residents of a long-term-care facility. Clin Infect Dis 1993;17:672-8.

28. Barbut F, Petit JC. Epidemiology of Clostridium difficile-associated infections. Clin Microbiol Infect 2001;7:405-10

29. Shim JK, Johnson S, Samore MH, Bliss DZ, Gerding DN. Primary symptomless colonisation by Clostridium difficile and decreased risk of subsequent diarrhoea. Lancet 1998;351:633-6.

30. Kyne L, Warny M, Qamar A, Kelly CP. Asymptomatic carriage of Clostridium difficile and serum levels of IgG antibody against toxin A. NEngl 7 Med 2000;342:390-7.

31. Larson HE, Barclay FE, Honour P, Hill ID. Epidemiology of Clostridium difficile in infants. 7 Infect Dis 1982;146:727-33.

32. Eglow R, Pothoulakis C, Itzkowitz S, Israel EJ, O'Keane CJ, Gong D, et al Diminished Clostridium difficile toxin A sensitivity in newborn rabbit ileum is associated with decreased toxin A receptor. 7 Clin Invest 1992;90:822-9.

33. Tabaqchali S, O'Farrell S, Nash JQ, Wilks M. Vaginal carriage and neonatal acquisition of Clostridium difficile. 7 Med Microbiol 1985;18:47-53.

34. McFarland LV, Brandmarker SA, Guandalini S. Pediatric Clostridium difficile: a phantom menace or clinical reality? 7 Pediatr Gastroenterol Nutr 2000:31:220-31.

35. Kim K, DuPont HL, Pickering LK. Outbreaks of diarrhea with Clostridium difficile and its toxin in day-care centers: evidence of person-to-person spread. 7 Pediatr 1983;102:376-82.

36. Wilson KH, Sheagren JN, Freter R. Population dynamics of ingested Clostridium difficile in the gastrointestinal tract of the Syrian hamster. $\mathscr{F}$ Infect Dis 1985;151:355-61

37. Tasteyre A, Karjalainen T, Avesani V, Delmee M, Collignon A, Bourlioux P, et al. Phenotypic and genotypic diversity of the flagellin gene (fliC) among Clostridium difficile isolates from different serogroups. 7 Clin Microbiol 2000;38:3179-86.

38. Seddon SV, Hemingway I, Borriello SP. Hydrolytic enzyme production by Clostridium difficile and its relationship to toxin production and virulence in the hamster model. 7 Med Microbiol 1990;31:169-74.

39. Borriello SP. Pathogenesis of Clostridium difficile infection. 7 Antimicrob Chemother 1998;41(Suppl C):13-9.

40. Poxton IR, McCoubrey JM, Blair G. The pathogenicity of Clostridium difficile Clin Microbiol Infect 2001;7:421-7.

41. Bongaerts GP, Lyerly DM. Role of toxins A and B in the pathogenesis of
Clostridium difficile disease. Microb Pathog 1994;17:1-12

42. Al-Barrak A, Embil J, Dyck B, Olekson K, Nicoll D, Alfa M, et al. An outbreak of toxin A negative, toxin B positive Clostridium difficile-associated diarrhea in a Canadian tertiary-care hospital. Can Commun Dis Rep 1999;25:65-9.

43. Barbut F, Lalande V, Burghoffer B, Thien HV, Grimprel E, Petit JC. Prevalence and genetic characterization of toxin A variant strains of Clostridium difficile among adults and children with diarrhea in France. 7 Clin Microbiol 2002;40:2079-83.

44. Anand A, Bashey B, Mir T, Glatt AE. Epidemiology, clinical manifestations, and outcome of Clostridium difficile-associated diarrhea. Am 7 Gastroenterol 1994;1994:519-23.

45. Kelly CP, Pothoulakis C, LaMont JT. Clostridium difficile colitis. N Engl f Med 1994;330:257-62.

46. Mylonakis E, Ryan ET, Calderwood SB. Clostridium difficile-associated diarrhea. Arch Intern Med 2001;161:525-33.

47. Rubin MS, Bodenstein LE, Kent KC. Severe Clostridium difficile colitis. Dis Colon Rectum 1995;38:350-4.

48. Triadafilopoulos G, Hallstone AE. Acute abdomen as the first presentation of pseudomembranous colitis. Gastroenterol 1991;101:685-91.

49. Kelly CP, LaMont JT. Clostridium difficile infection. Ann Rev Med 1998;49:375-90.

50. Dobson G, Hickey C, Trinder J. Clostridium difficile colitis causing toxic megacolon, severe sepsis and multiple organ dysfunction syndrome. Intensive Care Med 2003;29:1030.

51. Morris JB, Zollinger RM, Stellato TA. Role of surgery in antibiotic-induced pseudomembranous enterocolitis. Am 7 Surg 1990;160:535-9.

52. Lipsett PA, Samantaray DK, Tam ML, Bartlett JG, Lillemoe KD. Pseudo membranous colitis: a surgical disease? Surgery 1994;116:491-6.

53. Zimmerman MJ, Bak A, Sutherland LR. Review article: treatment of Clostridium difficile infection. Aliment Pharmacol Ther 1997;11:1003-12.

54. Kyne L, Warny M, Qamar A, Kelly CP. Association between antibody response to toxin A and protection against recurrent Clostridium difficile diarrheoa. Lancet 2001;357:189-93.

55. Barbut F, Richard A, Hamadi K, Chomette V, Beurghoffer B, Petit JC. Epidemiology of recurrences or reinfections of Clostridium difficile-associated diarrhea. 7 Clin Microbiol 2000;38:2386-8.

56. Wilcox MH, Fawley W, Settle C, Davidson A. Recurrence of symptoms in Clostridium difficile infection-relapse or reinfection? F Hosp Infect 1998;38:93-100.

57. Malnick SD, Zimhony O. Treatment of Clostridium difficile-associated diarrhea. Ann Pharmacother 2002;36:1767-75.

58. Peláez T, Alcalá L, Alonso R, Rodriguez-Créixems M, Garciá-Lechuz JM, Bouza E. Reassessment of Clostridium difficile susceptibility to metronidazole and vancomycin. Antimicrob Agents Chemother 2002;46:1647-50.

59. Wilkins TD, Lyerly DM. Clostridium difficile testing: after 20 years, still challenging. 7 Clin Microbiol 2003;41:531-4.

60. Delmée M. Laboratory diagnosis of Clostridium difficile disease. Clin Microbiol Infect 2001;7:411-6.

61. Vanpoucke H, De Baere T, Claeys G, Vaneechoutte M, Verschraegen G Evaluation of six commercial assays for the rapid detection of Clostridium difficile toxin and/or antigen in stool specimens. Clin Microbiol Infect 2001;7:55-64.

62. Barbut F, Kajzer C, Planas N, Petit JC. Comparison of three enzyme immunoassays, a cytotoxicity assay, and toxigenic culture for diagnosis of Clostridium difficile-associated diarrhea. 7 Clin Microbiol 1993;31:963-7.

63. Alfa MJ, Swan B, VanDekerkhove B, Pang P, Harding GK. The diagnosis of Clostridium difficile-associated diarrhea: comparison of Triage C. difficile panel, EIA for Tox A/B and cytotoxin assays. Diagn Microbiol Infect Dis 2002;43:257-63.

64. Staneck JL, Weckbach LS, Allen SD, Siders JA, Gilligan PH, Coppitt G, et al. Multicenter evaluation of four methods for Clostridium difficile detection: immunoCard $C$. difficile, cytotoxin assay, culture, and latex agglutination. $\mathcal{F}$ Clin Microbiol 1996;34:2718-21.

65. Gerding DN, Johnson S, Peterson LR, Mulligan ME, Silva J Jr. Clostridium difficile-associated diarrhea and colitis. Infect Control Hosp Epidemiol 1995;16:459-77.

66. Bélanger SD, Boissinot M, Clairoux N, Picard FJ, Bergeron MG. Rapid detection of Clostridium difficile in feces by real-time PCR. 7 Clin Microbiol 2003;41:730-4

67. Guilbault C, Labbé AC, Poirier L, Busque L, Béliveau C, Laverdière M. Development and evaluation of a PCR method for detection of the Clostridium difficile toxin B gene in stool specimens. 7 Clin Microbiol 2002;40:2288-90.

68. Rupnik M. How to detect Clostridium difficile variant strains in a routine laboratory. Clin Microbiol Infect 2001;7:417-20.

69. Manabe YC, Vinetz JM, Moore RD, Merz C, Charache P, Bartlett JG. Clostridium difficile colitis: an efficient clinical approach to diagnosis. Ann Intern Med 1995;123:835-40.

70. Fekety R. Guidelines for the diagnosis and management of Clostridium difficile-associated diarrhea and colitis. Am 7 Gastroenterol 1997;92:739-50.

71. Sehgal M, Kyne L. Clostridium difficile disease. Curr Treatment Options Infect Dis 2002;4:201-10

72. Tedesco FJ, Barton RW, Alpers DH. Clindamycin-associated colitis. A prospective study. Ann Intern Med 1974;81:429-33.

73. Fekety R, Silva J Jr, Kaufman C, Buggy BP, Deery HG. Treatment of antibiotic-associated Clostridium difficile colitis with oral vancomycin: comparison of two dosage regimens. Am 7 Med 1989;86:15-9.

74. Wenisch C, Parschalk B, Hasenhundl M, Hirschl AM, Graninger W. Compar- 
ison of vancomycin, teicoplanin, metronidazole, and fusidic acid for the treatment of Clostridium difficile-associated diarrhea. Clin Infect Dis 1996;22:813-8.

75. Teasley DG, Gerding DN, Olson MM, Peterson LR, Gebhard RL, Schwartz $\mathrm{MJ}$, et al. Prospective randomised trial of metronidazole versus vancomycin for Clostridium difficile-associated diarrhoea and colitis. Lancet 1983;2:1043-6.

76. Recommendations for the prevention of vancomycin resistance: recommendations of the Hospital Infection Control Practice Advisory Committee (HICPAC). MMWR Recomm Rep 1995;44(RR-12):1-13.

77. De Lalla F, Nicolin R, Rinaldi E, Scarpellini P, Rigoli R, Manfrin V, et al. Prospective study of oral teicoplanin versus oral vancomycin for therapy of pseudomembranous colitis and Clostridium difficile-associated diarrhea. Antimicrob Agents Chemother 1992;36:2192-6.

78. Young GP, Ward PB, Bayley N, Gordon D, Higgins G, Trapani JA, et al. Antibiotic-associated colitis due to Clostridium difficile: double-blind comparison of vancomycin with bacitracin. Gastroenterol 1985;89:1038-45.

79. Dudley MN, McLaughlin JC, Carrington G, Frick J, Nightingale CH, Quintiliani R. Oral bacitracin vs vancomycin therapy for Clostridium difficile-induced diarrhea. A randomized double-blind trial. Arch Intern Med 1986;146:1101-4.

80. Apisarnthanarak A, Razavi B, Mundy LM. Adjunctive intracolonic vancomycin for severe Clostridium difficile colitis: case series and review of the literature. Clin Infect Dis 2002;35:690-6.

81. Friedenberg F, Fernandez A, Kaul V, Niami P, Levine GM. Intravenous metronidazole for the treatment of Clostridium difficile colitis. Dis Colon Rectum 2001;44:1176-80.

82. Salcedo J, Keates S, Pothoulakis C, Warny M, Castagliuolo I, LaMont JT, et al. Intravenous immunoglobulin therapy for severe Clostridium difficile colitis. Gut 1997;41:366-70.

83. Medich DS, Lee KK, Simmons RL, Grubbs PE, Yang HC, Showalter DP. Laparatomy for fulminant pseudomembranous colitis. Arch Surg 1992;127:847-52.

84. McFarland LV, Elmer GW, Surawicz CM. Breaking the cycle: treatment strategy for 163 cases of recurrent Clostridium difficile disease. Am 7 Gastroenterol 2002;97:1769-75

85. Tedesco FJ, Gordon D, Fortson WC. Approach to patients with multiple relapses of antibiotic-associated pseudomembranous colitis. Am 7 Gastroenterol 1985;80:867-8

86. Buggy BP, Fekety R, Silva J Jr. Therapy of relapsing Clostridium difficile-associated diarrhea and colitis with the combination of vancomycin and rifampin. 7 Clin Gastroenterol 1987;9:155-9.

87. Tedesco FJ. Treatment of recurrent antibiotic-associated pseudomembranous colitis. Am 7 Gastroenterol 1982;77:220-1.

88. Surawicz CM, McFarland LV, Greenberg RN, Rubin M, Fekety R, Mulligan $\mathrm{ME}$, et al. The search for a better treatment for recurrent Clostridium difficile disease: use of high-dose vancomycin combined with Saccharomyces boulardii. Clin Infect Dis 2000;31:1012-7.

89. Surawicz CM, McFarland LV, Elmer G, Chinn J. Treatment of recurren Clostridium difficile colitis with vancomycin and Saccharomyces boulardii. Am 7 Gastroenterol 1989;84:1285-7.

90. McFarland LV, Surawicz CM, Greenberg RN, Fekety R, Elmer GW, Moyer $\mathrm{KA}$, et al. A randomized placebo-controlled trial of Saccharomyces boulardii in combination with standard antibiotics for Clostridium difficile disease. $7 A M A$ 1994;271:1913-8.

91. Gorbach SL, Chang TW, Goldin B. Successful treatment of relapsing Clostridium difficile colitis with Lactobacillus GG. Lancet 1987;2:1519.

92. Simor AE, Bradley SF, Strausbaugh LJ, Crossley K, Nicolle LE. Clostridium difficile in long-term-care facilities for the elderly. Infect Control Hosp Epidemiol 2002;23:696-703.
93. Worsley MA. Infection control and prevention of Clostridium difficile infection. 7 Antimicrob Chemother 1998;41(Suppl C):59-66.

94. Bettin K, Clabots C, Mathie P, Willard K, Gerding DN. Effectiveness of liquid soap vs. chlorhexidine gluconate for the removal of Clostridium difficile from bare hands and gloved hands. Infect Control Hosp Epidemiol 1994;15:697-702.

95. Johnson S, Gerding DN, Olson MM, Weiler MD, Hughes RA, Clabots CR et al. Prospective, controlled study of vinyl glove use to interrupt Clostridium difficile nosocomial transmission. Am 7 Med 1990;88:137-40.

96. Guideline for hand hygiene in health-care settings: recommendations of the Healthcare Infection Control Practices Advisory Committee and the HICPAC/SHEA/APIC/IDSA Hand Hygiene Task Force. MMWR Recomm Rep 2002;51(RR-16):1-45.

97. Struelens MJ, Maas A, Nonhoff C, Deplano A, Rost F, Serruys E, et al. Control of nosocomial transmission of Clostridium difficile based on sporadic case surveillance. Am 7 Med 1991;91(Suppl 3B):138S-44S.

98. Zafar AB, Gaydos LA, Furlong WB, Nguyen MH, Mennonna PA. Effectiveness of infection control program in controlling nosocomial Clostridium difficile. Am 7 Infect Control 1998;26:588-93.

99. Cartmill TDI, Shrimpton SB, Panigrahi H, Khanna V, Brown R, Poxton IR Nosocomial diarrhoea due to a single strain of Clostridium difficile: a prolonged outbreak in elderly patients. Age Ageing 1992;21:245-9.

100. Kaatz GW, Gitlin SD, Schaberg DR, Wilson KH, Kauffman CA, Seo SM, et al. Acquisition of Clostridium difficile from the hospital environment. Am $\mathcal{F}$ Epidemiol 1988;127:1289-94.

101. McNulty C, Logan M, Donald IP, Ennis D, Taylor D, Baldwin RN, et al. Successful control of Clostridium difficile infection in an elderly care unit through use of a restrictive antibiotic policy. 7 Antimicrob Chemother 1997;40:707-11.

102. Pear SM, Williamson TH, Bettin KM, Gerding DN, Galgiani JN. Decrease in nosocomial Clostridium difficile-associated diarrhea by restricting clindamycin use. Ann Intern Med 1994;120:272-7.

103. Climo MW, Israel DS, Wong ES, Williams D, Coudron P, Markowitz SM Hospital-wide restriction of clindamycin: effect on the incidence of Clostridium difficile-associated diarrhea and cost. Ann Intern Med 1998;128:989-95.

104. Surawicz CM, Elmer GM, Speelman P, McFarland LV, Chinn J, van Belle G. Prevention of antibiotic-associated diarrhea by Saccharomyces boulardii: a prospective study. Gastroenterol 1989;96:981-8.

105. Lewis SJ, Potts LF, Barry RE. The lack of therapeutic effect of Saccharomyces boulardii in the prevention of antibiotic-associated diarrhoea in elderly patients. F Infect 1998;36:171-4.

106. Thomas MR, Litin SC, Osmon DR, Corr AP, Weaver AL, Lohse CM. Lack of effect of Lactobacillus $G G$ on antibiotic-associated diarrhea: a randomized, placebo-controlled trial. Mayo Clin Proc 2001;76:883-9.

107. Kotloff KL, Wasserman SS, Losonsky GA, Tohomas WJ, Nichols R, Edelman $\mathrm{R}$, et al. Safety and immunogenicity of increasing doses of a Clostridium difficile toxoid vaccine administered to healthy adults. Infect Immun 2001;69:988-95.

108. Ward SJ, Douce G, Figueiredo D, Dougan G, Wren BW. Immunogenicity of a Salmonella typhimurium aroA aroD vaccine expressing a nontoxic domain of Clostridium difficile toxin A. Infect Immun 1999;67:2145-52.

Correspondence to: Dr. Andrew E. Simor, Department of Microbiology, Sunnybrook and Women's College Health Sciences Centre, B121-2075 Bayview Ave., Toronto ON M4N 3M5; fax 416 480-6845; andrew.simor@sw.ca

\section{Holiday Review 2004 Call for Papers}

We're looking for creative contributions for CMAJ's Holiday Review 2004. Humour, personal reflections, history of medicine, off-beat scientific papers and postcards from the edge of medicine are welcome.

Send your offering to the Managing Editor, Josephine Sciortino (800 663-7336 x2366; josephine.sciortino@cma.ca). Articles should be no longer than 1200 words, and photographs or illustrations are encouraged.

The deadline for submissions is September 13, 2004.

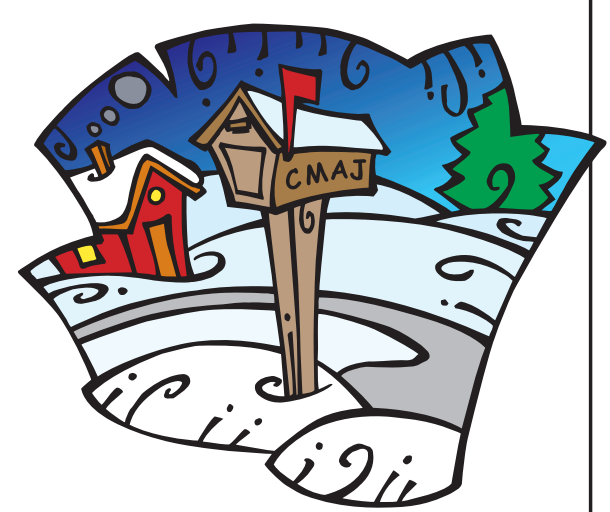

